\title{
The Media Framing of China's Image in East Africa: An Exploratory Study ${ }^{i}$
}

\author{
By Bob Wekesa* \\ PhD Candidate
}

Communication University of China, Beijing, China

\begin{abstract}
Sino-East African relations are very significant for the continent. These tightening, multilevel and overarching relations are to a certain extent dependent on the accumulation of perceptions among East Africans about China. China-Africa social science literature has pointed out that China has both a favourable and unfavourable image in East Africa. These studies however exhibit a certain level of vagueness from a communication perspective in so far as they lack empiricism. This exploratory paper investigates the media image of China in East Africa with a view to determining positive, negative and weak perceptions by applying a content analysis approach. I use a media framing model to investigate China's image as represented by four Nation Media Group English-language newspapers during 2011. As an exploratory study, the paper discusses some of the issues raised by the analysis, presents tentative findings and proposes further research directions ${ }^{\mathrm{ii}}$.

Predictions touting the imminent consignment of print media to history by new

*The author is a Kenyan journalist. He is currently a PhD candidate in International Communication at The Communication University of China in Beijing. He is a Commonwealth Press Union fellow and a frequent commentator in African and Chinese media.
\end{abstract}




\section{AFRICAN \\ EAST-ASIAN AFFAIRS \\ THE CHINA MONITOR}

media (OECD, 2010, Newspaper Death Watch, 2007, Poynter Institute, 2011) do not take cognizance of the fact that mainstream newspapers have re-invented themselves through online platforms (The Economist, 2012; Reiss, 2012; Pew Research Center, 2012), effectively blurring the line between their print and online versions. Indeed, while hardcopy newspapers are in decline in the West, they are showing double-digit growth in Africa and Asia (Christian Science Monitor 2010; NMG 2011).

Online or print, newspapers remain relevant as a platform for the social elite (see Holihan, 2008 for instance) compared to radio and TV. Elites' decisions are visited on the populace in a top-down, "two step flow" as theorized by Lazerfeld (discussed in Baran \& Davies, 2009, citing Lippmann, 1922; see also, Mills, 1956; Chomsky \& Herman, 1988).

Many images of China exist depending on which issues and individuals are involved (Peng, 2004). In order to identify how some of these images manifest in Africa, I have analysed the coverage of China in East African newspapers in 2011. Framing theory can serve as an approach to understand the media image of China in East African newspapers (Li \& Chitty, 2009).

\section{Framing concepts}

Framing as a field was conceptualized in 1974 by the sociologist Erving Goffman, as the classification, organization, and interpretation of life experiences (Pan \& Kociski, 1993). Framing is about mental codes of experience in relation to a particular organized mode of cognitive perception and response to complex situations. Frames denote clusters of ideas that enable individuals to locate, perceive, identify and label experiences. Drawing on Graber (1988), Entman (1993) says frames are close to concepts such as categories, scripts, or stereotypes that connote mentally stored clusters of ideas that guide individuals' information processing. This cognitive-inclined definition sees frames as an 
illumination of the precise way in which influence over human consciousness is exerted by the transfer of information.

For Morley (1976) cited in Reese (2001) framing is the "basic conceptual and ideological 'framework' through which events are presented and as a result of which they come to be given one dominant/primary meaning rather than another". Drawing on successive framing scholars, we can delineate the traits of a news frame as persistency/frequency/consistency, selection/placement, unique contextualization, inclusion/exclusion/insertion, emphasis/elaboration (Gitlin, 1980; Kahneman \& Tversky 1981, 1986; Gamson \& Modgiliani's, 1987; Tankard, et al. 1991, Entman, 1993; Pan \& Kociski, 1993; Reese, 2001; Vreese, Peter $\&$ Semetko, 2001). Texts (for example, newspaper articles) advocate certain ideas (Pan \& Kociski, 1993) and researchers have identified common 'central ideas' or news frames such as human impact/interest, attribution (of responsibility), powerlessness, economics (consequences), moral values/morality and conflict (Vreese, Peter \& Semetko, 2001; Semetko \& Valkenburg, 2000; Neuman et al. 1992).

Entman (1993) seminally conceives of framing as the selection of aspects of perceived reality, making them salient in a text, in such a way as to promote a particular problem definition, causal relationship, moral evaluation, and/or treatment. News framing has been theorized as involving sources, journalists and audiences and as a process that happens within four locations: the communicator, the text, the receiver, and culture; leading to encoding, interpreting, retrieving, constructing and processing news (Pan \& Kociski, 1993; Entman, 1993).

From the above definition of framing, I find the theory relevant to investigating how East African newspapers portray China. I would therefore start my research from the following hypothesis: media framing of the image of China in East Africa is more or less balanced between negative and positive perceptions because of the interplay of both negative and positive media frames. 


\section{AFRICAN \\ EAST-ASIAN AFFAIRS

\section{Generic and specific framing}

There are relaxed or unrestricted versus purist, strict or reductionist approaches to framing analysis. The field can be divided into two ideal-typical categories: specific and generic framing (Druckman, 2001; Vreese, Peter \& Semetko, 2001; Dimitrova, Kaid, Williams \& Trammell, 2005). Specific framing is best suited to small, narrow and explicit issues, events and case studies and is thus less suited to a subject as broad and complex as the image of China in East Africa. I would argue that a generic, thematic turn of framing is best suited to this study because our aim is to understand how East African newspapers portray China in a general sense rather than focusing on a single theme

\section{Weak and strong; negative and positive frames}

One can distinguish between weak and strong frames by drawing on the insight of Chong \& Druckman (2007) that "frequent exposure to a frame will increase the accessibility and availability of considerations highlighted by the frame". This will explain why certain headlines contribute either strongly or weakly to China's image.

The strength of a China frame in a newspaper article or articles increases with its perceived persuasiveness. Weak China frames in newspaper articles are typically seen as unpersuasive, whereas strong China frames are compelling for instance on the basis of tone and word choice (Druckman, 2001). The analytic focus in the data segment of this study falls on 1) How weak or strong the positive frames are and 2) how weak or strong the negative frames are. In other words, frames can be either very positive or not very positive and very negative or not very negative.

The assumption here is that strong frames result when the choice of codes leave little or no doubt that the frame is manifestly and patently negative or positive to the desired image of China. We assume that anybody interested in the positive 
image of China would see the headline as unequivocally positive and applaud it or the same individual would see the headline as negative and cringe. In addition to Chong \& Druckman's dichotomy between positive and negative on the basis of persuasiveness, we consider weak frames as those in which both negative and positive frames vie for prominence or are lucidly evident; where there is an apparent ambiguity and ambivalence, and where it is not immediately possible to decide whether strong feelings or perceptions can be elicited either way.

In this paper I will test to which degree weak and strong, positive or negative frames are discernible in East African newspapers' coverage of China.

\section{Methodology}

I use a quantitative, content analysis approach to systematically and objectively analyse and describe China coverage in East African newspaper texts (Kerlinger, 1986 cited in Wimmer \& Dominick, 2000). The sample is the four Nation Media Group (NMG) newspapers namely, Daily Nation (general daily news, Kenya), The Citizen (general daily news, Tanzania), Business Daily (business and finance Monday to Friday, Kenya) and The EastAfrican (niche market and specialized weekly, EAC region). The Daily Monitor of Uganda is the only NMG English print title omitted because of access limitations. By using private/commercial newspapers, we aim to find out how they portray China unswayed by officialdom.

Pan \& Kociski (1993) have pointed out that headlines are the most powerful framing devices in news items. My analytical units are all the headlines that have the word/code "China" or an explicit 'Chinese' element such as a national icon or place in them for the period of January to December 2011. This is a sufficient sample for an exploratory study that limits the danger of sampling errors (Wimmer \& Dominick, 2000).

Founded in 1959, the Nation Media Group (NMG) is publicly listed on the Nai- 


\section{AFRICAN \\ EAST-ASIAN AFFAIRS

robi Securities Exchange. According to my interpretation of the data on their website, the company approaches monopolistic tendencies in East and Central Africa (NMG, 2011). It's a multimedia company made up of over fifteen subsidiaries across the fields of newspapers, broadcasting, digital media, printing, courier services, transportation and ecommerce platforms (NMG, 2012) with operations in Kenya, Rwanda, Uganda, Tanzania and South Africa. In 2011 the company registered a turnover of Kshs11.25 billion (US\$967.5 million), an increase of 17.1 per cent on the back of the profitability of its newspaper circulation and advertisement revenue (NMG, 2012).

Two of the most common framing categories that scholars have described in previous research and which I use in this study are economic consequences and conflict frames (Vreese, Peter \& Semetko, 2001). The conflict frame relates to "the disagreement between individuals, institutions, or countries and emphasize points of divergence between conflicting parties" while the economic consequences frame is seen as a preoccupation with the bottom line, profit and loss (Vreese, Peter \& Semetko, 2001).

These two categories are wide enough to pinpoint the image of China in NMG publications. To support my content analysis, I developed a code sheet with the following elements: date, headline, economic (consequences), conflict, positive, negative, and weak. In addition, I developed a second category to specifically look at the following newspaper sections: 'hard news', 'soft news, 'opinion', and 'business'.

In quantitative communication research, scholars usually create categories or typologies for the purpose of undertaking newspaper content analysis. This makes the analysis clear in that the content, in this case headlines, must fall into certain slots as laid out above. This is as opposed to qualitative research where the soundness of arguments is the main methodological focus. We can look at categories as the slots we use to sort the vast amount of content available to us. 
Placing the content into these slots (for instance economic, conflict, hard news, positive, weak, etc), enable us not only to analyse it in terms of quantity but also to manipulate it in various ways. This allows us an empirical understanding of the perceptions and portrayals of China in East African newspapers.

\section{Results and Discussion}

How do the four NMG newspapers contribute to the positive, negative and weak media framing of China in East Africa?

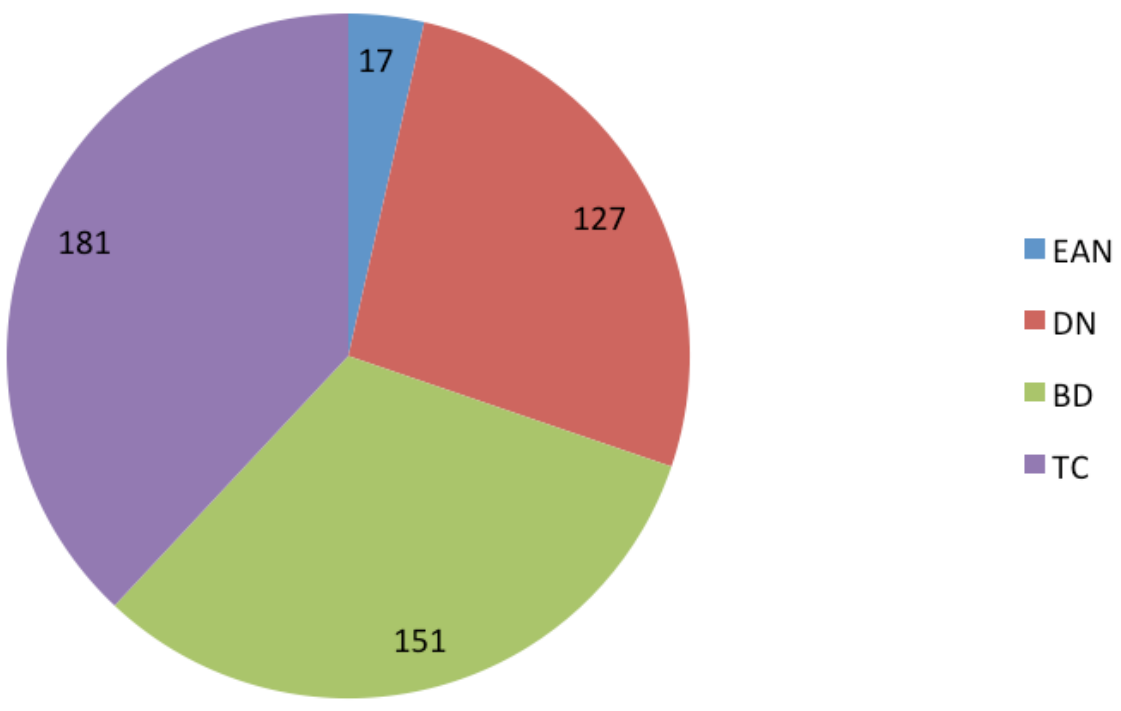

Figure 1: Coverage per newspaper (the numbers in each segment denote the number of headlines in each newspaper from January to December 2011). 


\section{AFRICAN \\ EAST-ASIAN AFFAIRS \\ THE CHINA MONITOR}

The Citizen has the highest number of China headlines followed by Business Daily, Daily Nation and EastAfrican.

\section{The EastAfrican (EAN)}

Comparatively, The EastAfrican has the lowest number of "China" codes, the overwhelming majority of which are economic consequence frames. It contributes only 6 per cent to the total number of positive frames and 0 per cent of negative frames. It has the highest percentage of positive frames of the four newspapers at 65 per cent while its negative and weak frames account only for 35 per cent. On average therefore, The EastAfrican is the most important newspaper to China's media image in terms of positive portrayal but the least in terms of frame frequency.

\section{Daily Nation (DN)}

Daily Nation is relatively balanced in frame selection between economic consequences and conflict frames. Overall however, it has more negative than positive frames, at 58 per cent and 43 per cent respectively, making it the newspaper that contributes the most to a negative media image of China in East Africa.

Overall, Daily Nation contributes 16 per cent to the total positive frames and 31 per cent to the negative frame, this being a high percentage of negative frame equivalence considering that it is ranked third in terms of frequency of reporting.

Of the four newspapers, Daily Nation is the only one that placed a negative China frame on its front page during the period analysed (Chinese firm loses Rwanda media license, April 24). The selection of this headline and its prominence can be seen as an attempt to highlight a negative depiction, particularly considering that Daily Nation ideally targets a Kenyan rather than Rwandan readership. Ordinarily this headline would not have made the front page. The article is 
about Star Times, a Chinese firm, that won a Kenyan government contract for digital signal distribution for which Daily Nation's parent company, NMG, had also bid. NMG also published editorial articles critical to China, and citing the case of the tender - a matter unfolding at the time of finalizing this paper. Other articles on this specific topic are illustrative: Chinese firm to control media signal (July 20), Chinese firm loses Rwanda media license (July 22 - apparently a carry-over from the April headline above), Contracting the services to a Chinese signals firm is capitalism gone amok, (July 22), Why is it risky for state and China to control media (July 24), to mention only a few.

Newspapers are not only pure conduits of news but also businesses and may see China as a competitor. For this reason their framing is occasionally self-serving rather than detached and objective. It would not be a stretch to expect that the 'Chinese media going out strategy' will equally be framed as Chinese media entering into competition with East African media. Commercial East African media conglomerates such as NMG may also have business partners and interests in other fields who might feel the heat of Chinese companies' closing deals especially with African companies and these interests could also find their way into headlines, as a number of headlines in this study affirm.

At the peak of negative valence, the framing concepts of persistence and equivalence are the most discernable in Daily Nation, for example: China warns over detained artists' image (May, 1), China frees rights lawyer but another disappears (May, 6), Defiant Christians petition China parliament on rights (May, 13), China boosts security in protest-hit region (May, 28).

\section{Business Daily (BD)}

Business Daily stands out as the newspaper with the highest number of economic consequences frames over conflict frames probably on account of being a business journal. The positive frames are roughly half more than the negative 


\section{AFRICAN \\ EAST-ASIAN AFFAIRS \\ THE CHINA MONITOR}

frames. Business Daily therefore has a higher equivalence of positive economic consequence frames and an equally high per capita rate of negative frames.

Business Daily has the second highest frequency of China framing of the four newspapers contributing 41 per cent of the positive framing and 39 per cent of the negative framing. An analysis of the headlines indicates the proclivity to dramatic framing of otherwise 'dry' economic themes. Examples include: Fundraising pressure piles on Chinese banks (January 17), Ambitious US firms wary of upsetting China (January 20), Kenya-China bilateral trade hits record KShs 144 billion [ $\$ 1.6$ billion] (February 24), Chinese firm tightens grip with Telkom Kenya KShs 4 billion [\$46.7 million] deal (March 18), Chinese in panic buying of salt (March 22), India tightens trade link with SA as it competes against China for major investments in Africa (April, 19), China's tighter ties with EAC signal new scramble for regional business (May 10), China tightens links with 'rich' Africa to feed thriving economy (June 1), China Apple frenzy triggers smuggling (July 26), Japan faces off with China over mega infrastructure deals (August 15), US shrugs off China's threat in trade (August 19).

\section{The Citizen (TC)}

Consistent with being the newspaper with the highest number of China codes of the four newspapers, The Citizen of Tanzania also has the highest number of positive and negative frames. However, internally, The Citizen has a positive rating of 49 per cent while the negative frames within the newspaper account for 37 per cent. The rest is made up of weak frames. The only positive front-page article within the analysed group of headlines is from this newspaper: Tanzania, China in $\$ 3$ billion mining deal (September, 22). This is followed by consistently positive units.

Though generally positive, The Citizen also carries negative headlines; Tanzania travellers cry foul over China visas (January 24) for instance, followed by the 
resolution of the matter in short order; China embassy extends visa application days (January, 31).

\section{National image}

The findings indicate that the image of China in East Africa is a complex matter that cannot be settled using a negative-positive dichotomy scale alone. Certain aspects of Chinese engagement serve to boost a positive image while others have the opposite effect. Because media framing of China is not linear, the emergent picture is also a potpourri of competing images, for instance with Daily Nation placing a critical story on its front page in July 2011 only for The Citizen to run with a positive front page article a few weeks later in September 2011.

\section{How often do the newspapers portray China within specific frames?}

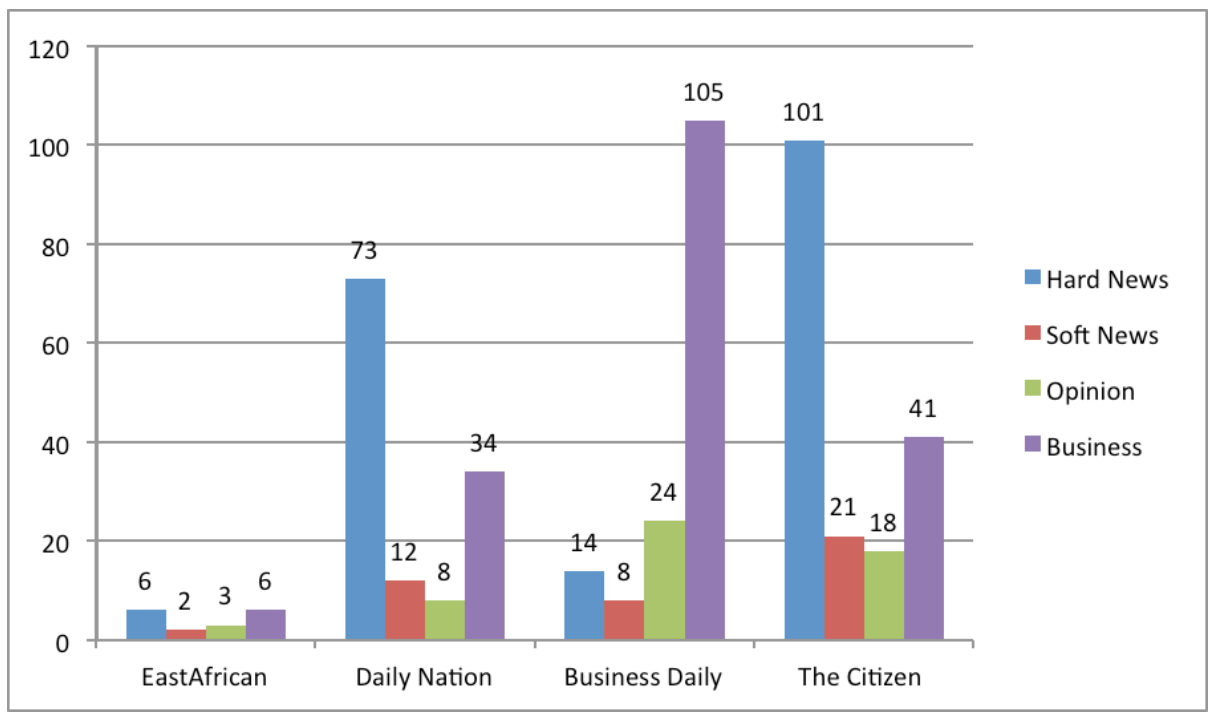

Figure 2: Newspaper section categorization: Hard news, soft news, opinion and business (note that vertical axis represents the number of headlines) 


\section{AFRICAN \\ EAST-ASIAN AFFAIRS

The two general news newspapers (The Citizen and Daily Nation) exhibit the highest frequency in the hard news category. The hard news section is labelled as news, international news, regional news, news in-depth, top news, county news, and so on. The margin between the hard news sections and the business news section is however not too wide. The business section, quite proximate to the economic consequences frame comprises units to do with economics, finance, investments, et cetera.

Soft news and opinion section units register comparatively lower reportage. Business Daily chalks up the highest number of opinion units at nearly half the total. The soft news category ('soft touch', human interest features, sports news and entertainment) is the least frequent. This section would perhaps be the most amenable to soft power and cultural diplomacy but the reality is that China coverage here is relatively paltry. Educational exchange, sports, cultural and entertainment events and high-level visits are favourably framed. However, most instances of cultural contact between China and East Africa are negative, such as when Chinese cuisine is framed as bizarre or when a love affair between a Chinese contract worker and a Kenyan woman sours.

Diplomatic initiatives that could be considered 'soft power' are turned into competitive, and potentially 'hard power' perceptions as evident in the headlines: China names envoy to Comesa in race for Africa trade (Business Daily, July) and China signs trade pact with EA in race for resources (Business Daily, November). Just when does soft power represent "a power of attractions" and when it is smart or hard power becomes quite a slippery conundrum.

\section{China's global firsts}

China's image takes a positive turn in units that position it according to global rankings. The athlete $\mathrm{Li} \mathrm{Na}$ stands out as regards to this kind of positive attribution. Other 'global first' frames can also be categorized as competitive frames, 
in that they relate to China outpacing or being on course to outpace the US economically, and as having already 'beaten' Japan. However, China's global firsts are not that popular with EAC media at the level of headlines.

\section{Country level analysis}

The issue of China's relations with other nations constitutes a fairly popular frame for newspapers. Of the 11 countries appearing with China in headlines, the US has the highest number of units confirming the competitive framing perspective of China-US relations in East Africa. This is particularly salient for economic frames. My findings suggest that media framing of China and the US in Africa is slightly in favour of China. However, weak frames are substantial in the China-US classification when compared to other kinds of data categorization - showing that the East African media can be ambivalent towards competition between China and the US. This further suggests that the East African media have their own independent views on this competition.

Other important nations linked with China in headlines are Sudan, Zambia and Zimbabwe, in that order. The frames in these headlines oscillate between Chinese investments, framed positively and conflicts between East African smallscale traders and Chinese immigrants, framed negatively. Another frame of proximity is the relationship between China and her Asian neighbours; Japan, South Korea, North Korea, Vietnam and the Philippines. The balance at this level of classification tends to turn more negative than positive and invariably focus on Asia-Pacific/South China Sea geopolitical dynamics.

\section{Elite framing}

Chinese leaders like then-President Hu and Premier Wen, contribute positively to the image of China with no negative framing directly attributable to them. Whenever Chinese leaders are framed negatively, they are not mentioned by name, with the newspapers settling for the amorphous "Chinese leader" attribu- 


\section{AFRICAN \\ EAST-ASIAN AFFAIRS

tion. The mention of presidents Bashir of Sudan and Mugabe of Zimbabwe by name is framed more 'weakly' rather than outright positively or negatively. The negative framing of China's relationship with Sudan is also portrayed using the amorphous "Sudan leader" wording. The highest frequency of negative framing of China's image by attribution is in combination with US President Barack Obama and then-US Secretary of State Hillary Clinton and invariably centres on human rights themes. Articles featuring opposition groups in China and quoting political dissidents are all negative.

What are the recurrent frames with an impact on the positive, negative and weak media image of China in East Africa?

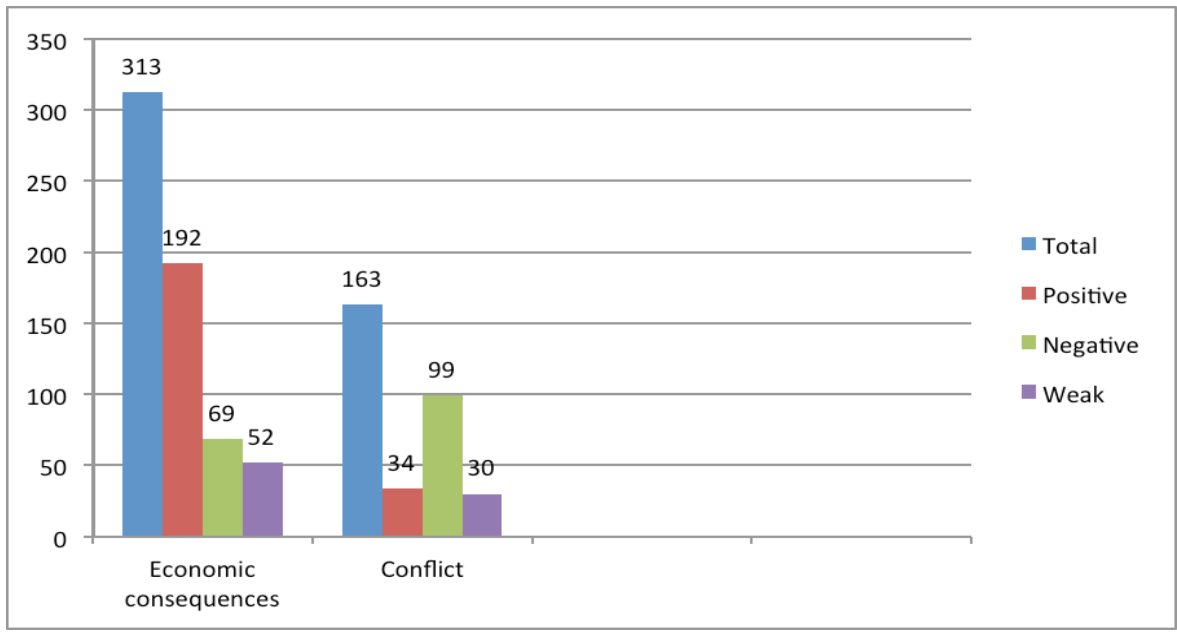

Figure 3: Economic consequences and conflict; positive, negative and weak (note that vertical axis represents the number of headlines)

The economic consequences frame or, more simply, economic themes occupy the lion's share of all the frames. This means that EAC media reports on China 
mostly focus on economic matters relating to profit and loss, trade and investments, various types of aid and engagement in the commerce and industry sectors. Economic consequences frames also contribute the most to the positive image of China.

Chinese companies are generally conflated with 'China' as a nation state/ country with most headlines not mentioning Chinese companies by name but rather predominantly using the phrase "Chinese firm". It is also evident that Chinese companies could cause negative framing, especially in a competitive environment and more so where African firms may be vying for deals with Chinese firms. Thus the conception of Chinese firms as an extension of the Chinese state is both an opportunity and a risk for China's image. Data analysis shows that only Huawei, the Chinese Exim Bank, Bank of China and Lenovo are directly mentioned, only one time in each case. The exception is Huawei, which is mentioned twice.

Conflict frames to do with governance, politics and democracy are less frequent than economic consequences frames. When we only consider the image of China as it relates to the conflict frame, independent of the economic consequences dimension, it emerges that the negative conflict frames are predominant in comparison to positive conflict frames.

\section{Positive, negative minus weak economic consequences and conflict}

Assuming that weak headlines are relatively moot to the extent that they are unpredictable without additional primary research, I experimented by removing them from the analytical field, ending up with data from units categorized as explicitly negative or positive, which yielded intriguing results.

Positive economic consequence units were the overwhelming majority, making up nearly half of the total. This left the remaining half to be shared by negative economic consequences units and positive and negative conflict units. When the 


\section{AFRICAN \\ EAST-ASIAN AFFAIRS \\ THE CHINA MONITOR}

positive economic consequences category and positive conflict category are looked at as one, they account for nearly three quarters of the headlines in the strong frame, thus contributing immensely to the positive image of China. This seems to indicate that when the East African press frame China strongly, they tend to do so in a positive way. At the same time, the ambiguity inherent to weak frames remains a grey area that demands more primary research to clearly ascertain the attribution of positive and negative weights.

\section{Trends and patterns}

Positive units fluctuate much more than the negative and weak units, while the weak frames show a stable trend throughout the study period. We also see the three categories (positive, negative and weak) rising and falling in a generally similar pattern, yet positive and negative units tend to fluctuate more violently.

The positive frames peaked in March. This is the period of the most marked positive construction of the image of China by the media. An analysis of the units during this period shows that all four newspapers favourably reported on the Chinese government's evacuation of its nationals from Libya during the 2011 civil war. The Libya crisis is framed in action-packed headlines depicting China as a country taking responsibility for its Diaspora (for instance, China keen to show it cares about workers in Libya, The Citizen, March 2011).

During this peak month there was a focus on high-level visits in Daily Nation and Business Daily as well as headlines that frame China's global economic growth, investments in East Africa, the prosperity of Chinese citizens and so on. Positive valance units in the conflict category are also heightened in this period. For instance, China's scrapping of the death penalty for thirteen non-violent crimes, a development reported in three of the four newspapers.

The positive category dramatically dips from its peak in March to its lowest level in April. Three plausible explanations for this are the conclusion of the 
evacuation of Chinese citizens in Libya leading to less positive units, more negative reporting on a Chinese media firm's competition with NMG for media contracts in Kenya and Rwanda, and a 'coincidental' increase in negative headlines such as China supporting dictators at the expense of Africans (Business Daily, July).

May is the peak of the negative reporting, with headlines invoking emotion and moral values rendered metaphorically. Most of the negative equivalence is centred round political issues within China such as dissidence, human rights and internet governance issues. The four newspapers predominantly sourced these articles from news agencies, most often from Agence France-Presse. This confirms the hypothesis that East African media are likely to follow Western media models. It is evident that the four newspapers rely heavily on Western news agencies, particularly Associated Press which in the analysed data is the main supplier of news to all the newspapers, accounting for 158 headlines out of the total 476. Does this reliance on the so-called "wire services" inadvertently advance what Alden (2006) refers to as a "Western discourse of fear"? It's noticeable that while a good number of the headlines from the agencies are positive or neutral, the bulk of the headlines on controversial issues involving China, such as human rights, friction with neighbouring countries and international and internal political dynamics, are sourced from the Western news agencies. Reuters, the other significant news agency is main source from which the specialized journal, Business Daily, selects the headlines, no doubt on account of Thomson Reuters's stature as a global financial data provider. In view of the framing concept of persistency and frequency and given the preponderance of Western News agencies in supplying news to East African newspapers, the need arises for further research. 


\begin{tabular}{|c|l|l}
\hline AFRICAN & Issue 1 \\
EAST-ASIAN & March 2013 \\
AFFAIRS & \\
\hline THE CHINA MONITOR & \\
\hline
\end{tabular}

\section{Is China's overall media image in the EAC positive, negative, or weak?}

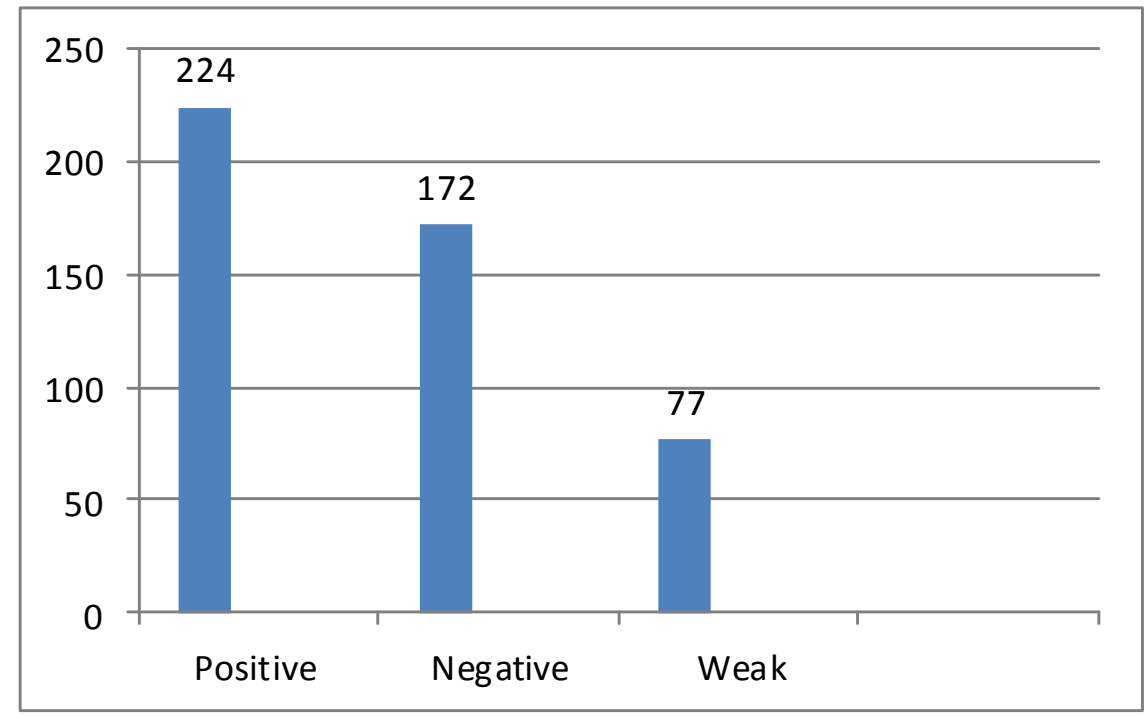

Figure 4: Overall positive, negative, weak (note that vertical axis represents the number of headlines)

The study finds that the image of China in East Africa is positive rather than negative or weak. The margin between negative and weak is also not overwhelming. However, when we compare positive and weak codes, the margin is substantially bigger. As we explained above, framing theorists tend not to take into account the possibility of neutral frames, only weak ones. In other words you cannot have perfectly balanced or non-existent feelings about China. For instance if we assume that there is an East African reader who has not heard about China at all, to the extent that a China headline draws absolutely no feel- 
ings from him or her, this hypothetical reader would frame the article in an extremely weak sense rather than completely neutrally.

An average reader who sees a 'weakly framed' headline, that is, one that is neither explicitly negative nor unequivocally positive may either have a positive or negative perception. Thus we may assume that weak frames can be read as positive or negative depending on the reader's prejudices. China enthusiasts will see a weak headline only in positive light; China-bashers will see a weak headline only in negative terms. Weak frames can therefore be seen as positive or negative depending on the disposition of the reader. Thus, when we contextualize weak frames in relation to positive and negative frames, we see that the image of China equally fluctuates from potentially very positive to potentially negative.

In addition, as we have seen in previous sections, readers are likely to be in favour of China in certain circumstances or topics and to disfavour it on others. To illustrate this point, consider the headline: Mama Clinton says: Africa, declare independence from China, India (The EastAfrican, June). We consider this a negative headline because China seems destined for criticism regardless of the fact that a reader enthusiastic about China might take a position critical to Clinton favourable to China. We thus categorize this headline in the negative category along with, say, Chinese chicken farmers ruffle Zambian feathers (Daily Nation, February). Is Kenya ripe for marriage with China? (Daily Nation, October) is a weak headline to the extent that it is a rhetorical and ambivalent headline in league with a headline such as Chinese firm tightens grip with Telkom Kenya Sh4 billion deal (Business Daily, March). The use of the word 'grip' would indicate a quite negative perception, except that the segment referring to a KSh 4 billion [ $\$ 46.7$ million] deal lends a positive tone. This is a hefty figure by Kenyan standards - thus the presence of negative and positive attributes renders the headline 'weak' in line with definition of the parameters for this paper. 


\section{AFRICAN \\ EAST-ASIAN AFFAIRS \\ THE CHINA MONITOR}

It is worthwhile to look at another headline that may be considered weak: The tiger and the dragon in hot race to woo Africa (The EastAfrican, May). Would readers see competition between China and India in Africa as good or bad? On the one hand, Africa would ultimately benefit from the competition through investment. On the other, a reader could be critical of two Asian powers turning Africa into their battlefield - why can't the dragon and the tiger conduct their 'hot race' in Asia? Another reader may be enthusiastic towards either China or India to the extent that in his/her mind, only one of these countries can be good for Africa. These and other ambivalent considerations inform the conception of weak frames as opposed to clearly negative or positive frames.

On the other hand, Chinese firm to inject $\$ 3$ million in coal, iron ore project (The EastAfrican, February), Hu pledges a peaceful and cooperative China in 2011 (Daily Nation, January), Tanzania and China sign \$1bn gas pipeline deal: Reuters (The Citizen, September) and Tanzania,China sign \$3 billion goal and iron ore contract (The Citizen, October) are examples of positively framed articles, even though they can be read otherwise by China critics. A perceptive reader with a nuanced view of the value of Chinese investments in Tanzania could raise legitimate criticism regarding various aspects other than the link to China thus resulting in a negative perception of the story. This notwithstanding, the balance of perceptions of these headlines is conceived as positive for the purposes of this paper considering that I use a face value definition of positive, negative or weak perceptions.

\section{Conclusion}

Our conclusion is resonant with Wesserman (2011) findings, that is, a more or less balanced image of China is discernible in East African media. Although my findings are that the media image of China is more positive than negative, I also found that the margin between positive and negative framing is not too wide. If the framing were significantly positive or negative, I would have concluded that 
my findings differ from my hypothesis. In broad terms, my conclusion affirms my hypothesis that: media framing of the image of China in East Africa is more or less balanced between negative and positive perceptions because of the interplay of both negative and positive media frames.

Framing analysts concur that constraints such newsroom routines, deadlines and news values influence journalists to make spur-of-the moment decisions in their selection of news items, which in turn tends to lead to the advancement of certain ideas (Entman, 1993). By selecting news agency copy, choosing how to fill pages or how to bring readers 'juicy stories' journalists may develop frames of mind about China that would only change through what Druckman (2007) calls a reorientation of thoughts. This calls to mind the conception of journalists as readers, in this case readers of the news agencies from which they persistently draw international news.

The main innovation of this paper is to bypass the issue of journalistic neutrality in favour of the concept of weak frames in line with established framing theorists' view that frames must be available and accessible in the memory of an audience in order to elicit a response (Scheufele \& Iyengar, forthcoming). Since the conception of weak frames creates a loop on the positive-negative image scale, I have tended to consider weak frames as either negative or positive. This model could be found relevant in exploratory, descriptive studies that seek to look at national image as the starting point for in-depth research. In addition, the model proposed here could be used to initiate further research drawing on interviews with news producers and consumers.

Regardless of the margin between positive and negative perceptions of China in East Africa, my findings are that China is generally seen in positive rather than negative light. Because the media is a microcosm of and indeed a reflection of the society in which it works, one can argue that in 2011 East Africans' perceptions of China were generally positive. The second major finding is that China's 


\section{AFRICAN \\ EAST-ASIAN AFFAIRS \\ THE CHINA MONITOR}

image in East Africa is both quantitatively and qualitatively inclined towards pragmatic, economic considerations.

\section{End Notes}

${ }^{\text {i }}$ This paper derives from the author's M.A. International Communication thesis at The Communication University of China, Beijing in July 2012.

ii The author acknowledges the support of the Communication University of China fraternity particularly international communication lecturers with special gratitude to Vice President Professor Hu Zhengrong, M.A supervisor Professor Zhang Yanqiu and Research Methodology lecturer Professor Zhao Jinqiu. CCS Executive Director Sven Grim and journal editor Cobus van Staden provided valuable guidance and editorial advice.

\section{Bibliography}

Baran, S \& Davies, D. (2009). Mass communication theory: Foundations, ferment, and future. Wadsworth. Boston, MA, USA.

Benford, D.R \& Snow, A.D. (2000). Framing process and social movements: An overview and assessment. Annu. Rev. Sociol. 2000. 26. 611-639. Retrieved March 2012 from http://web4.uwindsor.ca/users/b/basok/ main.nsf/6d8ffcfd02afe81e8525730600490ed8/178b2c68bafb979d852576a3005 33f46/\$FILE/ATTHBB9K/Benford\%20Snow\%20ARS.pdf

Centre for Chinese Studies. (2011). International conference: China-Africa relations and public diplomacy. Notes on conference held at Stellenbosch University, 15-16 August 2011. 
Chitty, N. (2011). IC, soft power and PD. International Scholar Workshop, Communication University lecture. Power point.

Chitty, N. (2008). China Soft. Revista do NP Comunicacao Audiovisual da Intercom, Sao Paulo, v.1, N.1, p.155-172 jan./jun.2008.

Chong, D \& Druckman, J. (2007). Framing theory. Annu. Rev. Polit. Sci. 2007. 10:103-26. Doi: 10.1146/Annurev.polisci.10.072805.103054. American Political Science Review. Retrieved April, 2012 from http:// faculty.wcas.northwestern.edu/ jnd260/pub/Chong\%20Druckman\%20Annual\% 20Review\%202007.pdf

Christian Science Monitor. (2010). Newspaper circulation blossoms in Kenya. (about double-digit growth in newspaper figures as the Western newspapers decline). Retrieved February, 20 2012, from www.csmonitor.com/World/Africa/ Africa-Monitor/2010/0808/Newspaper-circulationblossoms-in-kenya

Dimitrova, V.D., Kaid. L, L, Williams. P, W, \& Trammell, K, D. (2005). War on the web: The immediate news framing of Gulf War II. Press/Politics. DOI: 10.1177/1081180X05275595.

Druckman, J. (2001). On limits of framing effects: Who can frame? The Journal of Politics, 63, 4, 1041-1066. Cambridge University Press, Southern Political Science Association. Retrieved April, 2012 from http://www.unc.edu/ fbaum/ teaching/POLI195_Fal109/Druckman_2001_JOP.pdf

Entman, R. (1993). Framing: toward clarification of a fractured paradigm. Journal of Communication 43(4). Autumn. 0021-9916/93

Modgiliani, A \& Gamson, W. (1976). Thinking about politics. CRSO Working Paper, 146. Center for Research on Social Organization. Retrieved March 2012, from http://deepblue.lib.umich.edu/bitstream/2027.42/50921/1/146.pdf 


\section{AFRICAN \\ EAST-ASIAN AFFAIRS \\ THE CHINA MONITOR}

Nation Media Group. (2011). Annual report and financial statement. (company performance briefing to shareholders). Retrieved March 22, 2012 from www.nationmedia.com/docs/NMG_Annual

Report_Financial_Statements_2011.pdf

Nation Media Group. (2011). Corporate history. (about the profile of the company). Retrieved March 22, 2012 from www.nationmedia.com/about_us.html

New Vision. (2012). China hands over new President's office. Retrieved May 2012, from http://www.newvision.co.ug/news/628337-China-hands-over-new-President-s-office.html

Newspaper Death Watch. (2007). Chronicling the decline of newspapers and the rebirth of journalism. (statistics and trends of newspapers losing ground to new media). Retrieved March 20, 2012 from Newspaperdeathwatch.com/ index.php? $=$ an + industry + teetering + on + the + brink $+o f+a n+$ abyss

Pan, Z \& Kosicki, G. (1993). Framing analysis: An approach to news discourse. Political Communication, 10, 55-75. Taylor and Francis.

Peng, Z. (2004). Representation of China: An across time analysis of coverage in the New York Times and Los Angeles Times. Asian Journal of Communication, 14, 1, 53-67. Routledge.

Poynter Institute. (2012). (about the decline of newspapers circulation and advertisement). Retrieved May 14, 2012 from www.poynter.org/search/? $\mathrm{cx}=001006011763809941815 \% 3$ Anjuofsbjf248\&cof $=$ FORD3A10\&ie $=$ UTF- $8 \%$ $\mathrm{Q}$

Reese, S. D. (2001). Prologue - framing public life: A bridging model for media research. In Framing public life: Perspectives on media and our understanding of the social world. Reese, D., Gandy, O \& Grant, A. (eds.). 7-31. Retrieved March, 2012 from http://journalism.utexas.edu/sites/journalism.utexas.edu/files/ 
attachments/reese/framing-public-life.pdf

Saleem, N. (2007). US media framing of foreign countries images: An analytical perspective. Canadian Journal of Media Studies, 2(1). Retrieved May, 2012 from http://cjms.fims.uwo.ca/issues/02-01/saleem.pdf

Scheufele, D. (1999). Framing as a theory of media effects. International Communication Association. Retrieved March, 2012 from http:// www.asc.upenn.edu/usr/ogandy/c45405\%20resources/scheufele $\% 20$ framing\% 20as\%20effects.pdf

Scheufele, D and Iyengar, S. (Forthcoming). The state of framing research: A Call for new directions. The Oxford Handbook of Political Communication Theory. Retrieved May, 2012 from http://pcl.stanford.edu/research/2011/ scheufele-framing.pdf

Scheufele, D and Tewksbury, D. (2007). Framing, agenda setting, and priming: The evolution of the media effects model. Journal of Communication. Doi:10. 1111/j.1460-2466.2006.003.26.x. Retrieved February, 2012 from http:// www.scienzepolitiche.unimi.it/files/_ITA_/COM/3-Framing-AgendaSetting.pdf

Scott, M. (2009). The fall of Rome: Media after the empire. Lecture at A.N. Smith memorial lecture in journalism, University of Melbourne.

Tversky, A \& Kahneman, D. (1981). The framing of decisions and the psychology of choice. Science, New Series, 211, 4481, 453-458. American Association for Advancement of Science. Retrieved February, 2012 from http:// psych.hanover.edu/classes/cognition/papers/tversky81.pdf

Tversky, A \& Kahneman, D. (1986). Rational choice and the framing of decisions. Journal of Business, 59, 4/2. The Behavioral Foundations of Economic Theory. Retrieved February, 2012 from http://www.cog.brown.edu/courses/ cg195/pdf_files/fall07/Kahneman\&Tversky1986.pdf 


\section{AFRICAN \\ EAST-ASIAN AFFAIRS \\ THE CHINA MONITOR}

Van Gorp, B. (2007). The constructionist approach to framing: Bringing culture back in. Journal of Communication, doi:10.111./j.1460-2466.2006.00329.x., International Communication Association

Vreese, de C.H. (2004). The Effects of Frames on Political Television News on Issue Interpretation and Frame Salience. Journalism \& Mass Communication Quarterly, 81, 1, Spring 2004, 36-52. Retrieved March, 2012 from http:// www.claesdevreese.com/documents/de Vreese JMCQ 2004.pdf

Vreese, de C.H. (2005). News framing: Theory and typology. Information Design Journal, Document Design 13(1), 51-62. John Benjamins Publishing House. Retrieved March, 2012 from http://www.tveiten.net/futurelearninglab/ $\underline{\text { menu4/1233468300.pdf }}$

Vreese, de C.H., Peter, J \& Semetko, A.H. (2001). Framing politics at the launch of the

Euro: A cross-national comparative study of frames in news. Political communication, 18:107-122, 2001. Taylor and Francis. Retrieved March 2012 from http://www.claesdevreese.com/documents/

de_Vreese_Peter_\&_Semetko_PolComm_17.pdf

Wasserman, H. (2011). China in South Africa: The media's response to a developing relationship. Retrieved November 2011, from http://www.ru.ac.za/media/ rhodesuniversity/content/jms/documents/China\%20in\%20South\%20Africa.pdf

Wimmer, R. D \& Dominick, J, R. (2000). Mass media research: an introduction (6th edition). Belmont, California: Wadsworth Publishing Company.

Xiufang, L \& Chitty, N. (2009). Reframing national image. A methodological framework. Communication \& Conflict Online, 8, 2, 2009. www.cco.regener.de Zhou, Y and Moy, P. (2006). Parsing framing processes:The interplay between online public opinion and media coverage. Journal of Communication, 
http://aeaa.journals.ac.za/

doi:10.1111./j.1460-2466.2006.00330.x. Retrieved March, 2012 from http:// www.unc.edu/ fbaum/teaching/POLI891_Sp11/articles/J-Communication-2007 $-5 . p d f$ 